\title{
Geopolitical Challenges to Liberal Internationalism, the New World Order, and the Democratic Peace*
}

\author{
BRENDAN HOWE \\ Grathate School of International Studits, \\ Ewha Womans University.
}

\begin{abstract}
The post-Cold War "New World Order" bas been heralded as the fulfilment of the Kantian dream of demacratic perpetual peate long trumpeted by liberal internationaliss. Hnevere, while it is true that demacratic values are (for the moment) triumphant, and that universalism is riding pigg-back fashion upon waves of globalization, the victory is far from complete, and the process far frm inevituble. Univeratism is isself sabject to limiti. and those excluded from full partication may uell rebel against the chminance of the westem demacratic core. If uestern states do not uish iuch remil to gain momentum. the must take steps to ensure that the benefits of participation and economi uell being are not spread too unetienly acrols the globe.
\end{abstract}

Direc: all correspondence to brendan Howe, Assistant Professor of Graciuate School of International St:udies,

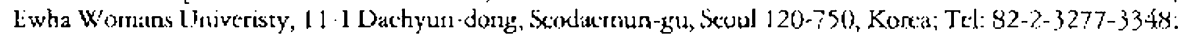

F.mail: hmghowe $\bar{x}$ hotmail.com 


\section{THE NEW NEW WORLD ORDER}

S ince the 'Realist' dominance of the 1950s and 1960s, thought about international $\checkmark$ urder reform and its influence upon the domestic policies of constituent states has experienced a resurgence," "to such an extent that we might be tempted to equate" the intellectual mood of the present time with the utopian impulse of the post-1918 decade." (Carlsnacs 1986,8) This process has picked up speed since the fall or communism. There is now perhaps a greater chatece of securing the post-First World War utopian aims of liberal internationalism in the contemporary environment of international normative consensus; but only if an international order is construcred that reflects a concern with legitimacy on the one hand but that recognizes and responds to structural dangers on the other.

With the end of the Cold War, a number of writers have advanced the hypothesis that an image of world politics consistent with that portrayed by Woodrow Wilson eighty years ago has now become applicable and appropriate. "Wilson's ideas and ideals now appear less unrealistic and more compelling. Old ideas are new again.' (Kegley 1995, 10) The advocates of such a workdvicw would tend to adhere to an optimistic (one might even say idealistic) vision of the inevitable march of democracy leading to a peaceful global community administered by shared values and the rule of law. A global concert of democratic states is the end goal. This worldview is reflected in President George Bush Seniur's 'New World Order' and the endism of Francis Fukuyama. For many, it is the fulfillment of Kant's vision of 'perpetual peace" - no competing ideology can now hope to challenge the dominant democratic paradigm, thus all states are moving inexorably towards eventual membership of the democratic club.

Merubership of this club, once it hecomes all-encompassing, precludes further armed conflice between states-democracies eend not to fight each other, as power rests in the hands of the people, and it is the people who suffer in times of war. It is also felt that greates openness within and between states in the international community decreases one of the chief causes of war conflict through misunderstanding, miscalculation and discrust. Thus, perhaps we can finally move the Kantian concept of perpetual peace from the category of utopian dream to that of practicable ubjective.

\section{THE INTERNATIONAL DIMENSION}

Earlier incarnations of this vision of an international society placed considerable emphasis upon the role played by the international community in furchering democratization. However, more recent work has tended to neglect the international context when analyzing democratic transition. Partly this is due to the modern tendency of demarcation of intellectual boundaries between academic disciplines, and partly because of the (until recent) dominance in international relations of theories that 
dichotomized the international and the domestic in political analysis. This paper contends that the international community still has a vital role to play in the consolidation of democracy in post-totalitarian states. By international community I refer specifically to the notion of a community of stable democratic states, the actions of which can impinge upon the interplay of domestic socio-political forces in transitional states. Thus I reject the international/domestic political dichotomy, and also the "billiard-ball" model of unitary rational states acting within an anarchic environment.

There are a number of ways in which the international community has in the past, and could it the future continue to favorably influence democratic transition. First therc is the notion of contagion from the West. It seems that in a similar manner to that feared by Western Cold War strategists concerning the spread of communism, democratic transition toppled one after another domino in the communist bloc. Democratic contagion spread from Poland to Czechoslovakia to East Germany to Hungary, Romania and Bulgaria in little more than a year, then to Albania, Slovenia, Larvia, the Russian Republic and Mongolia the following year. (Whitehead 1996, 5) Contagion from the West continues, especially with regard to the European Urion (EU) and North Atlantic Treaty Organization (NATO) and thosc states which wish to juin these organizations, but also in Southeast Asia where democratic contagion has influenced regime change in Cambodia and Vietnam, and in East Asia where democratic values have spread from America through Japan to Korea, and have even impacted upon China (although here the process might more adequately be termed contagion from the East!)

A number of post-Cold War peripheral states have shown a great inclination to make geopolitical sacrifices in the interest of peace (thereby playing by Western rules) in order to be accepted as part of the European cosmos. Finland has given up its claim to amputated Karelia (the cradlc of the Finnish nation), Hungary has renounced its claims upon Transylvania (the cradlc of Hungary) as well as parts of Slovakia, Ukraine and Serbia, and dominant Czechia acquiesced to a velvet divorce from an unhappy Slovak spouse. Likewise territorial disputes between Japan and Korea and Russia have not prevented improved relations between these countries.

The peoples of these councries are increasingly 'westernized' in their outlook, even to the extent of claiming that ' $(i) f$ it had not been for 'the system,' we would have been like the West.' (Przeworki 1991, 188) They, and the regimes representing them, have allowed considerable penetration of their societies by western media, cultural and economic organizations. Private organizations (from satellite television operators to car manufacturets), forcign state operations (from the $\mathrm{BBC}$ to overseas aid), and multi- and non-governmental organizations (from the World Bank to Save the Children) offer a constant diet of the advantages of belonging to the democratic $c l u b$, and put pressure on transitional regimes to move in a direction acceptable to this club.

Should this method of democratic encouragement not be sufficient, there lurks a more forceful argument for playing by western rules. The Western victory in the Cold War was as much military as economic or cultural. The Linited States and 
its allics now possess an overwhclming preponderance of military force with which to ensure that their world-view prevails. The West has in the past shown that it is not above imposing democracy upon countries that show tardiness in transition. According to Whitehead: "The essential point is that approacting two-thirds of the demoracies existing in $19 \%(0)$ owed their origins, at least in part, to deliberate acts of imposition or intervention from without (acts, morcover, lhat were undertakion within living memory)." (1996, 9)

For some commentarors, cven the (intbathey 'revolution' was imposed by the Wes: The 1975 Helsinki Final Act, which set up the Commission on Security and Cooperation in Europe (CSC:E) regime, also set up an international tramework that worked to systematically undermine the Soviet totalitarian vision. Thus it was not iust the general 'vitality and attractiveness' of the Western polity, but rather a specific coherent and disputed set of Western requirements, incentives, and reassurances embodied in an international treaty that shaped Moscow's foreign policy options in response to the Soviet Union's systemic crisis. (Whitehead 1996, 377-8) In addition. Richard Davy contests, the actions and strength of the West at this time served to stimulate the reenergence and cvolution of civil society in the countries of East-Central Europe. (Quored in whitehead 1996, 379)

The demise of the Inited Nations Security Council stalemate between, in ideological terms, diametrically opposed veto holders has increased the likelihood of intervention in support of democratic transition. The West appears to be in a position to dominate militarily, cconomically, politically, and even morally. Even should the W'est not choose to implement a program of direct intervention in support of democracy, it reruains in a pusition to inpose its wishes through cffective control ol multintional organizations transitional countries feel a strong imperative to join. Membership of such exdusive dubs can be conditional upon candidares atopeng regines with which the West feels comfortable the continued cxclusion of liurkey from the luropean Inion and (until very recently) of (hina from the World Trade Organization provide good examples of such a policy. President Clinton noted that 'multilateral action holds promise as never before' and that there now exists an opportunity to 'reinvent the insticutions of collective security." (Kegley 1995, 12)

European political leaders were also quick to recogrnize that the collapse of the Eastern bloc represented buth a threat and opportunity. (Dinan 199) 4, 65-6) Many bedieved that with the dearh of the Warsaw Pact, and the challenge posed by systemic change to NATO's raison d'ere. the European Community's hour had come with the end of the Cold War. (Hill 1996. 291) In true geopolitical style. there were (alls for the European Linion to fulfill ies destiny and come to represent the whole of the continent after which it was named and not jist the western half. Furthermore, wich the demise of the great "heartland" power, the USSR, and the partial withdrawal of the great "insular" power, the United States, renewed cfforts were made to builit the Union's political strength into something approaching that of its ecomotny.

Cersainly Arrick J.] of the Treaty on European Lnion (commonly known as the 
Maastricht Treaty), which introduced the Common Foreign and Security Policy seemed to 'talk the talk.' It promised 'to safeguard the common values, the fundamental interests, and the independence of the Union,' to 'strengthen the security of the Union and its member states in all ways;' to 'preserve peace and strengthen international security' and to 'promote international cooperation and develop and consolidate democracy and the rule of law and respect for human rights and fundamental freedoms.' (Regelsberger et al. eds. 1997, l (My emphasis))

This phenomenon overlaps somewhat with another aspect of international influence upon regime transition, that of consensual influence. If the West were to rely solely upon forced democratizarion, there may be no escape from Rousseau's famous paradox concerning the notion of heing 'forced to be free.' However, many transitional countries are on the whole, "freely' choosing democracy because of che attraction of the West. Such 'democracy by convergence' dictates that the most fundamental question concerns "how an almost universal wish to imitate a way of life associated with the liberal capitalist democracies of the core regions (the wish for moderniry) may undermine the social and institutional foundations of any regime perceived as incompatible with these aspirations.' (Whitehead 1996, 21) Primarily the attraction is economic. Yet for the countries of East-Central Europe this is not the whole story. There is also a perception that they share a common European cultural heritage with the West, and a common geopolitical identity with the Western European states of the European Union.

I'he lack of this perceived shared heritage is perhaps one of the greatest challenges to democratic transition and consolidation in Asia. Yat even here the concept of universalizing principles of right and wrong is taking hold. In September 1997 Robin Cook, the then British Foreign Secretary was lambasted by Malaysia's ptime minister Dr. Mahatir Mohamad for his so-called ethical foreign policy crusade when he singled out Myanmar's military junta for criticism. Accoriling to the Telegraph's Matt Frei, Dr. Malatir spoke for the region at that time when he told Asia Week: "The West thinks it is so very right and correct that it can sit in judgment of others and even prosecute people ... but the West has gor many sins." (1997) Mahatir also criticized the major article of faith of those who champion universal values, the Universal Declaration of Human Rights, pointing out that many Asian states were not able to participate in its drafting as they were under the boot of colonial oppression at the time. The buzi words then werc "Asian Values" and "sekampung," the Malaysian word for togetherness, which together supposedly reflected an alternative heritage emphasizing collective rights and duties to socicty rathet than "Western" individual rights. However, recent developments (May 2002) have apparently seen even the Malaysian government losing patience with the Myanmar Junta and applying pressure for the rclease of long-time pro-democracy leader Aung San Suu Kyi. Indeed, according to Allex Spillius, a release would be credited squarely to the efforts of Razali Ismail, a Malaysian diplomat and United Nations special envoy to Burma.

Various aspects of 'globalization' give further support to the notion of a peaceful 
world community of shared interests and norms governed by the rule of law. Chiets among these are the components of economic integration and interdependence that nuake it inherently unprofitable and thus irrational to fight major wars (multinational corporations, the twency-four hour global stock market, transnational capital flows, etc.) Finally, convironmental and social challenges facing humanity as a whole (global warming, ecological diversity, the ozone layer, the cnergy resources crisis, Malthusian population concerns, aids and drugs) may increase the pressure for conperation rather than competition among the various political subdivisions of humanity in the interest of species survival.

\section{CHALLENGES}

We should not. Krowever, place t(x) great an cmphasis upon the progress that global democratization has made in recent years. While many countries have been embroiled in regime transition, this has not necessarily led to democratic consolidation. Although there has becn a wave of democratizarion, Samuel Huntington is correct to warn us that such waves are usually followed by corresponding (if more limited) waves of counter-democratic auchoritarianism, and that democratization tends to follow a two-step-forward, one-stcp-back pattern. (1991, 25) In particular, staces undergoing a regime transition are at their most volatile, a danger to their own people and to their neighbors. Thus we must always be awase in our brave now world order that not all transitions from authoritarian rule result in democracy.

Likewisc, we should not rely absolutely and unquestioningly upon the continued inregration of the global economy. First, many analysts ate of the opinion that the process is about to move into reverse, with increased tariff barticts placed in the way of frce trade, increased economic regionalism and attempts at regional autarchy perhaps even going as far as the development of exclusive regional trading blocs. Second, the effects of economic globalization are not cvenly distributed by no means all groups or all socicties benefit equally, or even ar all from the process. Even if this were not the case, there is no guarantee that economic interdependence would lead to the climination of conflict. As far back as the beginning of the twentieth century, writcrs such as Norman Angell (1911) pointed out that wariare is no longer a rational instrument of policy for this very reason, yet that century saw the bloodiest and inost destructive wars in the history of mankind.

Indeed, individuals often act according to a different rationality than that of economic well being. Furthermore, it is by no means certain that the global threats to mankind's existence will engender coopcration indeed, many analysts would argue that Malthusian comperition for limired resources is more likely to lead to a cut-throat world embodying Darwinian notions of "survival of the fittest." This world-view has led to the emergence of an alternative multipolar vision of the future that of a world divided into compering politico-cconomic blocs. This is not a new concept. The German geopoliticias, general 
and professor, Karl Haushofer, provided perhaps the most (in-) famous exposition of this view as a justification for German expansion during the Nazi period. 1 Haushofer's pan-tegions foresaw the world being divided into a number of autarkic political and economic zones, within each of which a single great power would hold sway and exploit the resources of vassal states and regions, excluding the influence and participation of its great power rivals. The model for these regions would be the role played by the United States in the Americas under the Monroe Doctrine indeed, contemporary versions of this vision have referted to these regions as 'Montoes.'2

The theoretical underpinning for this approach is the belief that hard 'geoeconomics' functioning as instruments of national policy are not played out in terms of 'win-win' cooperation, but rather as aspects of a zero-sum game. States are more interested in relative economic positioning and getting a larger share of the cake, than they are in increasing the size of the cake so that all may benefit albeit to a lesser extent. These perceived geopolitical challenges reinforce those dangers emphasized by authors who continue to write in accordance with the tenets of the realist paradigm in international relations. For them, nothing has really changed since the con of the Cold War, and the new New World Order is every bit as utopian as the old inter-war one. East-West tensions remain, and although things may be somewhat more peaceful berween superpowers at the moment, the potential remains for a resumption of conflict and contradictory ideologies indeed, if anything the post-Cold Wat environment could be even further from the universalist ideal as there are now, with the inclusion of China, two potential challengers to democratic values. Realists not only reject the notion of achieving a universal consensus based on peaceful norms and beliefs, but also the integration preject the continuing primacy of the state within an anarchic international environment is seen as a firm reality for the forcsecable future, with the EU representing nothing more than a metastate fulfilling all of the traditional statecentric functions concerning powet and national interest. (Baylis 2001, 271)

For Neorealists like Kenneth Waltz, "states are made functionally similar by the constraints of structure, with the principle differences among them defined according to capabilities.' $(1995,80)$ States are seen as autonomous political units, with autonomy being the counterpoint of anarchy at the structural level, and anarchy not varying with content. Thus 'the logic of anarchy obtains whether the system is composed of tribes, nations, oligopolistic firms, or street gangs.' (Waltz 1995, 81) This logic is one of competition and relative gains rather than cooperation and absolute gains for all. Even democratic states must be wary of other democratic states, for as pointed out by Johin Mearsheimer in a number of works since the end of the Cold War, not only has the end of that confrontation led to an increase in hot wars around the world, but also that "the possibility always exists that a democracy will revert

\footnotetext{
'See Howe, Brendan. 1993. "Geopolitics, Geopolitik, and Nazi Foreign Policy." M.A. Dissertarion, Liniversicy of Kent at Canterbury.

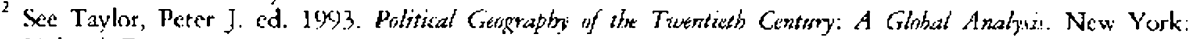
Halsted Press.
} 
to an authoritarian state. Liberal democracies must therefore wotry about relative power anong themselves. Lamentably, it is not possible for cven liberal democracies to transcend anarchy." (see Ray 1995, 346)

\section{THE IMPIJCATIONS}

This paper does not set out to refute Kantian claims of the pacifying influence of democracy, interdependence or mombership of international organizations upon states. Such effects have been adnirably and empirically demonstrated by (among a distinguished list of many others) Russett and $\mathrm{O}^{\prime} \mathrm{Ncal}(200 \mathrm{I})$, Weart (1998) and Benoit (1996). Russet and O'Neal describe these promises as the three sides of the Kantian triangle $(2001,35)$ and have demonstrated the independene pacifie effect of cach (albeit with significantly less confidence with regard to the systemic effects of international governmental organizations). Rather, what is atcempted here is an assault on the complacency inherent in the liberal belief in incvitable progress and the failure of such scatistical analysis as carried out by authors such as those mentioned above to take inco account sub-and trans-state socio-political influences and novements. Thus, in general, this paper sets out to sound a nute of caution against an overlypetmistic belief in the functioning of "virtuous circles." (Russett and O'Neil 2001 , 34-41)

Russett and O'Nical find that democracies ate inherenty more pacitic, and in particular for pacific dyads, regardless of the age of the democracy (120). That is as may be. However, the age of the democracy is not really the issue, and this could be seen as something of a straw man. Whar is more important is the stability of a new democracy. Here sub- and trans-state influences have garncted an increasing role. Jikewise it is perfectly possible to accept that a network of developed and increasingly interdependent states is likely co encuurage the development of pacitic dyads between, but raise the challenge that interdependence per se can also be a source of conflict at a sub-or trans-state level. Finally, while accepting that shared membership of international organizations can have a pacific effect on the behavior of states, particularly if pacific foreign and domestic policies are made in pre-requisite for membership, what is at issue is whether membership is open to all, and if so whether is is traly in the form of a free association.

The importance of these developments for ransitional states cannot be overemphasized. We must remember that the (old War was not won by "democracy" but rather by a closely allicd geopolitical bloc of democratic states. Of crucial relevance is where the genpolitical line is drawn, should regionalism become a fact, and certain states face exclusion from the European and North American core. As pointed out by Ole Tunander, this question represents a synthesis of a "bipolar friend-foe structure" and at 'hierarchical cosnos-chaos structure.' (1\%)7. 17) It is by no means certain that the Western core will accept all its peripheral suitors. Indecd, it is already apparent 
thar Russia and the Lkraine have, to a considerable extent, been rebuffed.

\begin{abstract}
Reason has its limits, and the transferring of reason to the alien world presupposes a possible common code, a possible enlightened, transparent workl beyond the shadows of Otherness. According to universalism, these dark shadows are not first and foremost to be contained, they must be rolled back and finally annihilated by the light of reason if not by reason, then by force. The existence of a Wall (or geopolitical division betwecn cosmos and chaos) speaks of the limits of universalism and about the Other as a fundamental concept. (17)
\end{abstract}

Thus we must consider the exclusion of certain states, which wish to become part of the core to be not only a possibility, but rather a probability. What then is likely to happen to the process of democratic transition within these countries? First and foremost, a point will come where such countries and sucietics will cease to model themselves upon those shining examples and role-models by which they have been rcbuffed. Excluded from one cosmos, it is likely that they will attempt to create an alternarive one. This may take the form of an alcernative form of democracy, but thete is no guarantee that this will be the case. It may be based on the Chinese model of 'Socialism with Chinese characteristics.' Alternatively, it may be hased upon a concept similar to that of 'Asian values.' Perhaps Islam will throw up an alternative cosmos or core of values and power. Whatever the case, if the ideological blueprint of Western/universalist democracy is rejected, it is likely that what emerges in its place will be less democratic, and maybe cyen hostile to the West and its values. If one state sets foot upon such a path, it is important to recognize that there is every chance of the contagion process acting in reverse. This could involve not only the transmission of material favorable to the newly evolving less than democratic cosmos, but also transmission of the democratic good life from which individual states, societies or regimes might perceive themselves to be irredeemably excluded.

It is also likely that the controlling influence of the West in favor of democratic transition will be diminished. In particular, here the European Union is already showing a rather mixed record. Brussels responded with alacrity to the end of the Cold War, establishing PHARE programs of technical assistance to aid seven East European countries in their transtormation. "However, the Community failed to maintain this momentum, in part because of its internal conflicts over Maastricht and economic and monetary union, in part because the disintegration of Yugoslavia and the USSR uncovered deep differences of prioritics within Western Europe about how to handle the collapse of the Soviet bloc.' (Whitehead 1996, 381-2)

Although recently, and particularly since the Amsterdam Treaty and the im. plementation protocols included in the Nice Treaty, the European entargement project appears to have resumed, with a number of accession negotiations underway with Baltic, Eastern European, Balkan and Mediterranean countries, the pace is still 
painstakingly slow, and the democratization process could even stall in some of the countries queuing up for membership before consolidation bencfits are felt. Furthermorc, common foreign policy and security provisions have proven to be the must resistant to agrecment in the within the EU, and each potential enlatgement advetsely cffects the interests of existing member states. Finally, for every state that sees its chances of joining increasing, there is another that sees the door being ever more firmly closed in its face. Even if this were not the casc, evidence from psychological experiments indicatc that the success of some members of a group actually decreases the contentment of other members of a group that either feel jealously, resentment at the success of others, or disappointment due to an expectancy gap generated by inflated aspirations growing at a faster rate than satisfaction of expectations.

The willingness of the West to pay for the New World Order has proven remarkably short lived. First, there is considerable pressure upon the major protagonists to cash in on the 'peace dividend.' Second, with the (at least temporary) abcyance of the Soviet threat, other security considerations command the attention of the West one of the reasons why the crisis in Former Yugoslavia proved such a failure of collecrive security policy was that attention was distracted by unfolding events in the Culf. Finally, the removal of a common enemy has lead the major Western powers to look toward their own particular interests and compete with each other for primacy, further undermining support for collective action or individual responsibility. Indeed. recent statements by the German government cast doubt on where the money will be found for those currently under consideration. Furchermore, In their relations with transitional states Western powers often look to cultivare protg regimes rather than promote democratic transition and consolidation per se. Rwanda provided a horrific demonstration of partisan support, with the French supporting a Francophile regime that gave every appearance of genocidal tendencies against an English speaking rebcl movement, while the United States supported the very short lived 2002 Venezuclan military coup against the democratically elected but pro-Cuban President Chavez.

The consensual process of democratic transition is also under threat. The Western way of life only exerts a positive attraction as long as it is perceived to be desirable and preferable to other alternatives. Should the capitalist democratic world system enter a pronounced downturn this may no longer be the case, particularly if increased inter-regional competition should lead on a new wave of protectionism and shrinking

global trade. Furthermore, the promised benefits of democratic transition have been slower to materialize within transirional states than many may have hoped. Something of an expectancy gap has developed, and may lead to a degree of discontent sufficient to undermine or even reverse the liberalization that has already taken place.

\section{THE INTERNAL MECHANICS OF DEMOCRATIC TRANSITION}

The process of democratic transition itself is a source of considerable uncertainty 
and hardship. Some groups are bound to lose out, at least in the short term. Support for transition is only generated by the general optimism that ultimately all will benefit; the hope that even if this is not the case, then at least the majority will do so; and the common belief held by most, that they will form part of this majority. As pointed out by Pridham, such uncertainty may be exciting and creative, 'but if it becomes too generally threatening, or if it lasts tou long without fruitful outcome, then the chances of an authoritarian relapse becomes very great.' (1991, 5)

The optimism and expectuncy of a large number of individuals and groups in transitional states may have been misplaced. More than any other form of government, democracy depends for its legitimacy upon the consent of a majority of those governed. In order to generate and maintain such consent, democracy must provide what the majority of people want. It is not necessary here to enter into the debate about which sort of regime is more likely to promote development and economic success. All that is necessary is to recognize that democracy is dependent to a certain extent for its survival upon economic factors (whether more or less dependent than authoritarian regines is again irrelevant at this juncture), and that to some degree it has failed to fulfill the expectations of the citizens of a number of transitional states within this arena. This may have been in part due to the unrcalistic initial expectations of people in the first place. However, that does not make the threat to democratic consolidation any less real.

Evidence suggests that a citizen's political perceptions vary in accordance with economic citcumstances, (Maravall 1997, 201) and many countries are currently in what Przeworski terms the 'valley of transition,' faced with four potential outcomes: (1) Reforms may advance under democratic conditions. (2) Reforms may advance through dictatorship. (3) Democracy may survive by abandoning reforms. (4) Both reforms and democtacy may be undermined. (1991, 138) The inevitable costs of transition include corruption, inflation, underemployment of capital and labor, allocative inefficiencies and distributional effects. No matter the universal aspirations, no reform makes all hetter off, and certainly some will always benefit more than orhers. Any group that perceives itself worse off in relative, let alone absolute terms is therefore likely to resist the implementation of the reform. Transitional states are faced with two courses of action, a gradualist reform path, or a bitter pill strategy designed to right as many social reforms in as short a time as possible. The majority of states have accepted the OECD cant:

While a gradualist approach may cause lesser social tensions, a long period of moderate reforms entails the danger that both reformers and the population will 'become tired of reforms, as they do not seem to bring visible changes. Also during long periods of reforms various anti-reform and other lobbies may mobilize their forces and may gradually strangle the reform process. ${ }^{3}$ 
Thus the bitter pill has tended to be swallowed. Linfortunately, even when people do support the radical treatment at the outset, this support crodes, often drastically, as social costs are experienced. (Przeworski 1941. 167) The supposedly short, sharp. shock of the bitter pill strategy can appeat to go on for an inordinately long period of rime.

\section{ALTERNATIVES}

Such developments need not necessarily pose a threat to democratizarion as long as democracy is seen as "the only game in town." No matter how great its failings, if there is no plausible alternative, then democracic transition is not likely to be seriously undermined. I lowever, circumstances in a number of transitional states would appear ideal for throwing up an alternative to democracy. The Islamic fundanenealist chreat is of course to the fore of most uhserver's minds. However, nationalist, antiwestern sentiments are also prevalent in China, Russia, Iatin America, Africa and Southeast Asia. Comparisons with the German inter-war transitional experience can usefuliy be drawn at this point. From the very ourset of the post-war economic order there were those, including advisors at the Versailles negotiations such as Keynes and Mackinder, who worried whether the Cermans had been lett with sufficient economic power to build a democratic scate. The Silesian coalfields were annexec by Poland, and the Saar region was given over to France. Even after the years of hyper-inflation (which destroyed savings and led to the alienation of the middle class) had hinally becn put hehind them, Weimar poliricians were still due more economic disasters than any govemment could hope to cope with. "Not only the German Crovernment, bue the states, the big cities, even the churches, as well as industry and business, borrowed at high rates and short notice, spending extravagantly without much thought of how the loans were to be repaid except by borruwing more." (Bullock 1962, i13)

When, in light of their own financial problems, American loans were called in, Germany was left more susceptible than any other country to the Great Depression which began in the United States in 1929, intensified and spread n 1930 and 1931 , and lasted throughout 1932. Keynes later claimed that by destroying the German economy, the allies sowed the seeds of Naxism. Germany could not connete, was forced to become an autarkic state, and had to grab markets physically rather than sell chrough free trade (especially after the collapse of the British led free trade system) to avoid the foreign economic "scueeze. Many transitional states are similarly strugry lingr to compste, and there is a growing awareness of the uneven distribution of the fruits of globalization. To a certain extent the anti-WTO riots of recent munchs and the horrendous terrorist actions of September $1 f^{: 11} 2001$ spring from this same source.

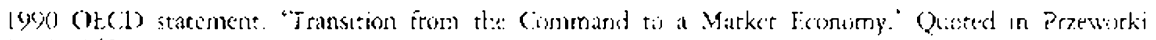

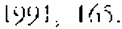




\section{CONCIUSION}

Although Samuel Huntington's work on the Clash of Civilizations and his concept of the 'call of the blood' has come under a rigorous bombardment from Western academics, it is disturbingly apparent that his ideas resonate fairly strongly with academics and practitioners of foreign policy within a number of transitional states. As mentioned by Russett and O'Neal, the danger lies in its porential not just to interpret events, but also to shape them thereby 'becoming a self-fulfilling prophecy, intensifying conflicts ur bringing about some that utherwisc would not have occurred.' $(2001,241)$ In order to facilitate democtatic transition and consolidation, it is vital that the West not isolate these countries geopolitically and economically, but rather provide material and moral support to those actors most concerned with democratic values, and to the regimes as a whole. If this is not done, there is just as likely to be an anti-democratic counter-wave as a New World Order of perpetual peace based on shared values. 'lhis may continue to take the form of disaffected groups within transitional states operating through one or another means of direct action, or just as conceivably, the form of an increase in the numbers of rogue states who rejecr the rules of liberal internationalism and chreaten the return of a true international atrarchy.

The current members of "international socicty" have considerable rational incentive to maintain their collective action, but the growth of this community to encompass other states is far from racionally pre-ordained. Presene members actually have a number of rational incentives to resist expansion. More members will possibly lead to more costs in terms of incegracion and involvement in conflictual areas. Wider membership also almose inevitably means greater policy divergence, and therefore increasing strains upon the coalition and diminishing individual policy returns. Firrally, more partners means that the profits of incumbency (i.c. world leadership) must be spread more thinly.

Thus it would be rational to predict that the "Euro- $A$ t lantic cosmos" will be maintaincel as a minimal winning coalition, containing sufficient members to take control of the fixed prize of office and no more. It is also not rational for surplus states to seek to join an already winning coalition, as they will halve no leverage and thcrefore cannot expect to reap any rewards, only contribure to costs. (Sce Laver 1997, 138) However, it is in the rational self-interest of the current winning coalition to dissuade attacks such as those that occurred on Scptember 11, 2001. It may be that the most cost-effective way of doing so is to rcmove the discontent which fuels such extreme acts, and actively manage the functioning of the "virtuous circle" of democracy, interdependence and international organisations through a degree of social enginecring and enlightened benevolence, rarher than building up resentment through suppression simply because we currently have the wherewithal to do so. 


\section{REFERENCES}

Angell, Norman. 1911. The Great lllasion. New York: G.P. Putnam.

Baylis, Johrı, 2001. "International and Global Security in the Pose-cold War Era," In The Glubalization of World Politios. Baylis, John and Smith, Steve eds. Oxford: Oxford Lniversity Press.

Benoit, Kenneth. 1996. "Democracies Really are Morc Pacific (in General): Reexamining Regime Type and War Involvement." Joumal of Confict Resolution 40 (4): 636-657. Bullock, Aian. 1962. Hitler: A Study in Tyranny. Harnondsworth: Pelican.

Carlsnaes, Walter. 1986. Ideology and Foreign Policy: Problems of Comparative Conceptualiom. Oxtord: Basil Blackwell.

Diamond, Jarry, Linж, Juan, and Lipset, Seymout Martin cels. 1995. Politics in Dezeloping: Countries: Comparing Experiences with Democraty. $2^{\text {nd }}$ Edition. Boulder: Lynne Ricnner.

Dinan, Desmond. 199/. Ever Closer Linion: Basingstoke: Macmillan.

Frei, Matt. 1997. Robin Conk's Moral Crusade Enruges Asia's fiencest Tiger. The Telegraph $7^{\text {r.l. }}$ September 1997.

Hill, Christopher. 1996. The Actors in Eusopes Foretgn Policy. London: Routeledge.

Huntington, Samud P. 1991. The Third Wave: Democratization in the Late Tuentieth Century. Norman, Oklahoma: Liniversity of Oklahoma Press.

Kcgley, Charles W. Jr. 1495. Contmeries in Intemational Relations Theor: Realism and the Neoliberal Challenge. New York: St. Martin's Press.

Laver, Michael. 1997. Private Desires, Palitical Action: An Invitation to the Politics of Rational Choure. London: Sage.

Maravall, Jose Maria. 1997. Regimes, Politics, and Markets: Demaratization and Lconomit Change in Sautbem Europe and Eastem Europe. New York: Oxford University Press.

Pridham, Geoffrey, ed. 1991. Encouraging Democraty: The International Context of Reginue Tranition in Siluthem Eumpe. New York: St. Martin's Press.

Prreworski, Adam. 1991. Democracy and the Market. New York: Cambridge University Press.

Ray, James Lee. 1995. "Promise or Peril? Neorealism, Neoliberalism, and the Future of International Politics." In Contronersies in International Retations Tboory. Kegley, Charles, W. Jr. ed. New York: St Martin's Press.

Regelsberger, Elfriede et al. eds. 1997. Forign Policy of the Furopuan Linjon: From EPC to CFSP and Reyond. London: Lynne Rienner.

Russer, Bruce and O'Neal, John. 2001. Triansulaing Peate: Democrac", Interdtendenct, and International Onganizations. Nea: York: Norton.

Spillius, Alex. 2002. Buma to Retease Democracy leader from Houre Arrest. The Telegtaph $1^{\text {st }}$ May 2002.

Tunander, Ole ct al. eds. 1997. Geppolitics in Pojt-Wall Europe: Seturiby, Territory and ldentity. I.nndor: Saze.

Waltz, Kenneth. 1995. "Realist Thought and Veorealist Theory." In Contwersies in Intemational Relations Thermy. Kegley, Charles, W. Jr. ed. New' York: St Martin's Press.

Whitehead, Iaurence ed. 1996. The International Dimunsions of Democratization: Etimpe and the Americas. New York: Oxford Liniversity l'ress. 